\title{
ПІДВИЩЕННЯ НАСІННЕВОЇ ПРОДУКТИВНОСТІ МАТЕРИНСЬКИХ ФОРМ СОНЯШНИКУ
}

\author{
В. О. Веселий ${ }^{1}$, В. П. Коломацька ${ }^{1}$, О. М. Брагін ${ }^{2}$ \\ ${ }^{1}$ Інститут рослинництва ім. В. Я. Юр'єва НААН \\ ${ }^{2}$ Харківський національний аграрний університет ім. В. В. Докучаєва
}

В статті наведено результати вивчення сестринських стерильних гібридів соняшнику, отриманих з участю індукованих мутантних ліній. Встановлено тенденції в змінах основних господарських ознак та виділено цінні комбінації, які значно перевищують вихідну форму за урожайністю каліброваного насіння, що підтверджує доцільність використання сестринських гібридів в підвищенні урожайності материнських форм соняшнику.

Соняшник, мутантна лінія, стерильний гібрид, урожайність, сестринське схрещування

Однією з важливих характеристик гібрида соняшнику є урожайність його материнської форми. Цей показник, при рівноцінності інших якостей, надає значну перевагу при вирощуванні насіння гібриду та його поширенні. Підвищити урожайність материнської форми можливо різними методами, майже всі з яких вперше було розроблено та випробувано в селекції кукурудзи [1]. Існуючі методи можна поділити на два основні напрямки, один 3 них передбачає покращення продуктивності самозапилених ліній, інший використання як материнської форми стерильного гібрида [2].

Використання стерильного гібрида як материнську форму на ділянках гібридизації повністю знімає проблему насіннєвої продуктивності материнських форм у відносно короткий термін, але веде до створення іншого типу промислових гібридів - трилінійних. Порівняння недоліків і переваг простих міжлінійних та трилінійних гібридів наведено в чисельних публікаціях, деякі з цих питань є дискусійними [3].

Збільшення врожайності материнської форми простого міжлінійного гібриду шляхом введення в його формулу третього батьківського компоненту дуже часто викликає ряд негативних наслідків, притаманних трилінійним гібридам. По-перше, знижується врожайність новоствореного гібрида, а по друге - його вирівняність за морфологічними ознаками, ступінь якої в окремих випадках заважає проходженню тесту на однорідність в державних органах реєстрації. Для вирішення цих проблем як третій компонент гібрида запропоновано використовувати лінію близькорідну до материнської. Отже,

(C) В. О. Веселий, В. П. Коломацька, О. М. Брагін. 2012.

ISSN 0582-5075. Селекція і насінництво. 2012. Випуск 102. 
в такій гібридній комбінації материнською формою виступає сестринський стерильний гібрид. Цей метод досить поширений в селекції кукурудзи для створення простих модифікованих гібридів [4].

Для створення сестринських гібридів кукурудзи широко використовують схрещування індукованих мутантів з вихідними лініями. Як свідчить Моргун В. В., використання цього методу дає позитивні результати і $є$ досить перспективним [5]. Результати про підвищену продуктивність сестринських гібридів кукурудзи, отримані від схрещування індукованих мутантів 3 їх вихідної лінією, підтверджено також іншими дослідниками [6]. В селекції соняшнику цей метод підвищення врожайності материнських форм соняшнику поки що не набув належного поширення, але має безперечну актуальність і перспективу застосування.

В Інституті рослинництва ім. В. Я. Юр'єва НААН реалізовано широку програму зі створення мутантних ліній з використанням хімічного мутагенезу, що дало можливість значно розширити колекцію лінійзакріплювачів стерильності [7].

Метою досліджень $є$ встановлення рівня показників господарських ознак у сестринських стерильних гібридах, створених з участю індукованих мутантних ліній, та доцільності їх використання для збільшення урожайності насіння материнських форм соняшнику.

Методика досліджень. Дослідження проведено в східній частині Лісостепу України на полях наукової сівозміни Інституту рослинництва ім. В. Я. Юр'єва НААН впродовж 2008-2010 рр. Роки досліджень значно відрізнялись за динамікою температурного режиму і вологозабезпеченості протягом вегетаційного періоду соняшнику.

Матеріалом для досліджень були лінії селекції Інституту рослинництва ім. В. Я. Юр'єва НААН: стерильний аналог вихідної лінії Х 908Б - Сх 908А та сім мутантних ліній-закріплювачів стерильності (Мх 215Б, Мх 53Б, Мх 7Б, Мx 42Б, Мх 1091Б, Мх 168Б, Мх 4Б), отриманих за допомогою хімічного мутагенезу з вихідної лінії. Сестринські гібриди було отримано від схрещувань стерильного аналогу вихідної лінії з усіма мутантними лініями.

Дослідження проведено в розсаднику попереднього випробування на дворядкових ділянках обліковою площею $10,25 \mathrm{~m}^{2}, 3$ схемою розміщення $0,7 \times 0,25$ м 3 однією рослиною в гнізді, при триразовій повторності та розміщенням стандартів на кожній 10-тій ділянці. Впродовж вегетації проведено фенологічні спостереження 3 визначенням повних сходів, цвітіння та фізіологічної стиглості. Обліки проведено індивідуально на 50 рослинах, крайові рослини в кожному з рядків не враховували. Визначено продуктивність і масу 1000 насінин з кожного кошика 3 перерахуванням до стандартної вологості $12 \%$ за загальноприйнятими методиками [8-10]. Вимірювання висоти рослин та діаметру кошика проведено через 30 діб після цвітіння. Кількість квіточок в кошику визначено шляхом підрахунку квіточок у круговому секторі одразу ж після цвітіння. Вологість насіння визначено із застосуванням вологоміру. Кількість сім'янок з кошика та кількість листків 3 рослини визначали шляхом підрахунку, вміст олії в насінні за допомогою 
екстракційного методу [11]. Розміри решіт при калібруванні насіння стерильного гібрида відповідали стандарту [12].

Результати досліджень. За результатами досліджень встановлено, що урожайність насіння (табл. 1) у сестринських гібридів, створених 3 участю індукованих мутантів, коливається в значних межах (1,01-2,29 т/га). Виділено дві комбінації Сх 908А / Мх 215Б та Сх 908А / Мх 42Б, що мають достовірно збільшену врожайність насіння (1,87 та 2,29 т/га відповідно) у порівнянні з стерильним аналогом вихідної форми Сх 908А / X 908Б $(1,06 \mathrm{\tau} / \mathrm{ra})$.

Урожайність каліброваного насіння серед вивчених зразків також мала значні відміни й коливалась від 0,64 до 1,88 т/га. Достовірно більшим відносно стандарту цей показник був у тих самих Сх 908А / Мх 215Б та Сx 908A / Мх 42Б, і відповідно становив 1,47 і 1,88 т/га, що понад два рази перевищило урожайність вихідної форми - 0,69 т/га. Слід відмітити, що різниця в урожайності каліброваного насіння досягнута не тільки за рахунок збільшення загальної урожайності, але й за рахунок збільшення виходу насіння цих форм.

Вихід насіння у сестринських гібридів, створених з участю індукованих мутантних ліній, коливався в межах 59,6 - 82,2 \%. При цьому достовірно меншим від стандарту $(65,5 \%)$ цей показник спостерігався в комбінації Сх 908А / Мх 53Б (59,6 \%), а достовірно більшим - в трьох сестринських гібридах: Сх 908А / Мx 1091Б - 70,2 \%, Сx 908А / Mx 215Б - 78,2\%, Cx 908A / Mx 42Б-82,2\%.

Таблиця 1

Урожайність материнських форм соняшнику, створених шляхом сестринських схрещувань 3 участю індукованих мутантних лінійзакріплювачів стерильності, 2008-2010 pp.

\begin{tabular}{|c|c|c|c|c|c|}
\hline \multirow{2}{*}{$\begin{array}{c}\text { Материнська } \\
\text { форма }\end{array}$} & \multicolumn{2}{|c|}{$\begin{array}{c}\text { Урожайність } \\
\text { насіння }\end{array}$} & \multicolumn{2}{|c|}{$\begin{array}{c}\text { Урожайність насіння } \\
\text { після калібрування }\end{array}$} & \multirow{2}{*}{$\begin{array}{c}\text { Вихід } \\
\text { насіння, } \\
\%\end{array}$} \\
\hline & т/га & \pm до St & т/га & \pm до $\mathrm{St}$ & \\
\hline Cx 908A / Mx 168Б & 1,01 & $-0,05$ & 0,64 & $-0,05$ & 63,1 \\
\hline Сх 908A / Mx 53Б & 1,10 & 0,04 & 0,66 & $-0,04$ & 59,6 \\
\hline Cx 908A / Mx 1091Б & 1,12 & 0,06 & 0,79 & 0,10 & $70,2^{*}$ \\
\hline Cx 908A / Mx 163Б & 1,18 & 0,12 & 0,74 & 0,05 & 62,8 \\
\hline Сx 908A / Mx 4Б & 1,22 & 0,16 & 0,81 & 0,12 & 66,5 \\
\hline Cx 908A / Mx 215Б & $1,87 *$ & $0,81 *$ & $1,47 *$ & $0,78^{*}$ & $78,2 *$ \\
\hline Cx 908A / Mx 42Б & $2,29 *$ & $1,23 *$ & $1,88^{*}$ & $1,19 *$ & $82,2 *$ \\
\hline Cx 908A / X 908Б, St & 1,06 & & 0,69 & & 65,5 \\
\hline $\mathrm{HIP}_{05}$ & & 0,21 & & 0,19 & 4,2 \\
\hline
\end{tabular}

Аналіз показників структури врожайності та інших цінних господарських ознак досліджуваних сестринських стерильних гібридів показав, що вони мають достовірні відмінності від стандарту (табл. 2). 
为

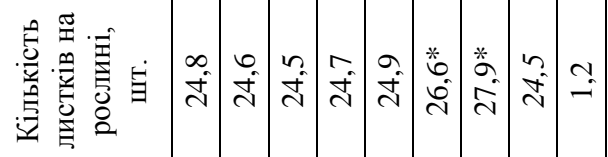

ㄴ.

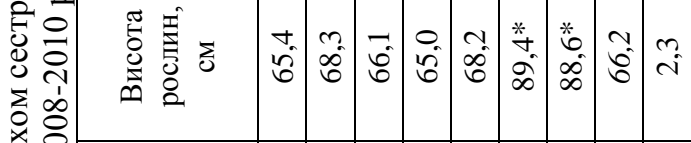

뜽 웅

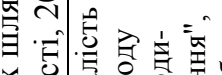

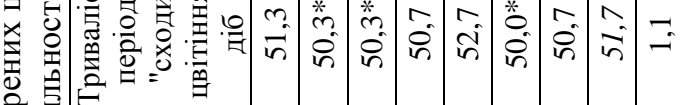

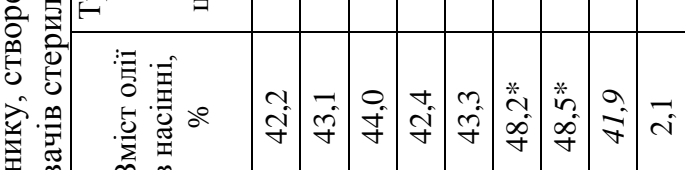

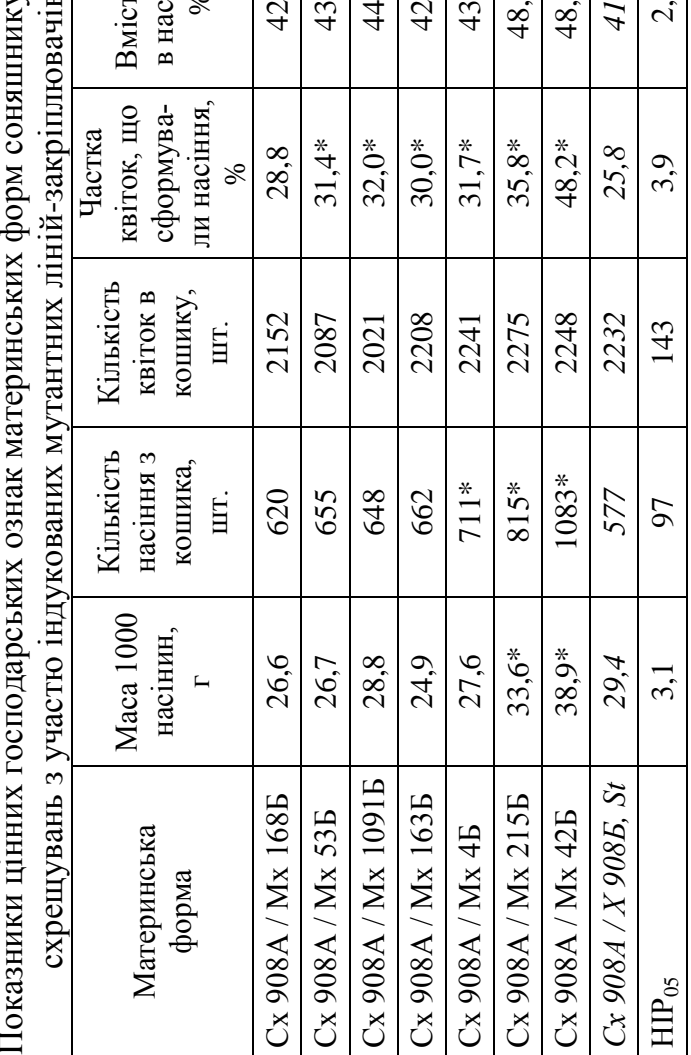


Так, коливання маси 1000 насінин у сестринських гібридів, спостерігається в обидва боки відносно стандарту. Достовірно меншою від вихідної форми $(29,4$ г) масою 1000 насінин характеризується комбінація $\mathrm{Cx} 908 \mathrm{~A} / \mathrm{Mx} 163 Б$ - 24,9 г, а збільшеним цей показник $\epsilon \quad \mathrm{y}$ Cx 908A / Mx 215Б - 33,6 г та Сx 908А / Mx 42Б - 38,9 г.

Кількість насіння з кошика має чітку тенденцію до збільшення в усіх комбінаціях сестринських схрещувань (620-1083 шт.) по відношенню до вихідної форми (577 шт.). Три 3 семи досліджених комбінацій Сx 908А / Мx 4Б, Сх 908А / Мx 215Б, Сх 908А / Мх 42Б мають достовірно збільшену кількість насіння з кошика - відповідно 711, 815 і 1083 шт.

Кількість квіток в кошику в досліджених комбінаціях схрещувань знаходилась в межах 2021-2275 шт. і в жодному випадку достовірно не перевищувала вихідну форму - 2232 шт. В комбінаціях Сх 908А/ Мх 53Б (2087 шт.) та Сx 908А / Мх 1091Б (2021 шт.) показники кількості квіток в кошику $\epsilon$ достовірно меншими від стандарту.

Частка квіток, що сформувала насіння, у сестринських гібридів коливалась від 28,8 до 48,2 \% і мала чітку тенденцію до збільшення в порівнянні 3 стандартом (25,8 \%). Що, безумовно, є наслідком збільшення кількості насіння 3 кошика 3 одночасними незмінністю або зменшенням кількості квіток у порівнянні з вихідною формою.

Вміст олії в насінні коливався в межах 42,2-48,5 \%. Більшість комбінацій не мали достовірних відмін від вихідної форми (41,9\%), окрім двох зразків, тих самих, що мали підвищену врожайність насіння. Комбінації Сх 908А / Мх215Б та Сх 908А / Мх 42Б мали вміст олії в насінні відповідно 48,2 i $48,5 \%$.

Тривалість періоду "сходи-цвітіння" досліджених сестринських гібридів змінювалась від 50,0 до 52,7 діб, в той час як цей показник у вихідної форми дорівнював 51,7 діб. Достовірно менший період "сходи-цвітіння" від стандарту мають комбінації $\mathrm{Cx} 908 \mathrm{~A} / \mathrm{Mx} 215 \mathrm{5}$ (50,0 днів), Сx 908А / Мх 1091Б (50,3 днів), Сх 908А / Мх 53Б (50,3 днів). Комбінацій 3 достовірно збільшеним періодом "сходи-цвітіння" не виявлено.

Висота рослин більшості досліджених комбінацій є на рівні вихідної форми (66,2 см). Виключенням $є$ комбінації зі збільшеною врожайністю насіння - Сх 908А / Мх 215Б - 89,4 см., Сх 908А / Мх 42Б - 88,6 см вони мають достовірно збільшену висоту рослин у порівнянні зі стандартом.

Анологічна ситуація спостерігається за показником кількості листків на рослині - достовірні відмінності від стандарту (24,5 шт.) мають комбінації Сх 908А / Мх 215Б - 26,6 шт., Сх 908А / Мх 42Б - 27,9 шт.

Таким чином, встановлено, що у сестринських стерильних гібридів соняшнику, створених з участю мутантних ліній, показники кількість насіння 3 кошика та частка квіток, що сформували насіння, мали тенденцію до збільшення і нерідко достовірно перевищували вихідну форму, показники маси 1000 насінин достовірно змінювались як в бік зменшення, так і в бік збільшення, кількість квіток в кошику та тривалість періоду "сходицвітіння" знаходились на рівні, або були меншими, показники вмісту олії в 
насінні та кількості листків на рослині були на рівні або більшими від вихідної форми. Виділено сестринські гібриди, які перевищують вихідну форму за урожайністю каліброваного насіння на 0,78 та 1,19 т/га, що підтверджує доцільність їх використання в підвищенні урожайності материнських форм соняшнику. Виділені комбінації характеризуються також покращеними показниками маси 1000 насінин, кількості насіння з кошика, вмісту олії в насінні, збільшеними висотою рослин та кількістю листків на рослині.

Найкращі за врожайністю насіння сестринські гібриди залучено до створення і подальшого вивчення модифікованих гібридів соняшнику.

\section{Список використаних джерел}

1. Кириченко В. В. Селекция и семеноводство подсолнечника (Helianthus annuиs L.)/ В. В. Кириченко - Х., 2005. - 385 с.

2. Деякі принципи створення та покращення гібридів кукурудзи в інституті рослинництва ім. В. Я. Юр'єва УААН / Л. В. Козубенко, М. М. Чупіков, Т. П. Камишан [та ін.] // Селекція і насінництво : міжвід. темат. наук. зб. УААН, Ін-т рослинництва ім. В. Я. Юр'єва. - Х., 2005. - Вип. 91. - С. 47-55.

3. Мырза В. П. Селекция простых модифицированных гибридов на стерильной основе : автореф. дис. на соискание учен. степени канд. с.-х. наук : спец. 06.01.05 "Селекция и семеноводство" / В. П. Мырза. - Одесса, 1980. -23 c.

4. Врожайність районованих гібридів кукурудзи та їх модіфікованих аналогів / М. М. Чупіков, Н. С. Овсяннікова, І. П. Барсуков [та ін.] // Селекція і насінництво: міжвід. темат. наук. зб. УААН, Ін-т рослинництва ім. В. Я. Юр'єва. - Х., 2006. - Вип. 93. - С. 118-128.

5. Моргун В. В. Экспериментальный мутагенез и его использование в селекции кукурузы / В. В. Моргун - К.: Наук. думка, 1983. - 280 с.

6. Кравченко В. М. Вплив рівня гетерозису сестринських схрещувань на основні господарсько-цінні ознаки модифікованих гібридів кукурудзи : автореф. на здобуття наук. ступеня канд. с.-г. наук 06.01.05 - селекція рослин / В. М. Кравченко. - Днепропетровск, 2007. - 22 с.

7. Кириченко В. В. Хімічні мутагени та поліпшення ліній соняшнику/ В. В. Кириченко, В. І. Пов’якало// Селекція і насінництво: міжвід. темат. наук. зб. - К.: Урожай. - 1998. - Вип. 80. - С. 19-20.

8. Зерновые, зернобобовые и масличные культуры : Сб. Ч. 2. - М. : Изд-во стандартов, 1990. - 319 с.

9. Методика государственного сортоиспытания сельскохозяйственных культур. Масличные, эфиромасличные, лекарственные и технические культуры, шелковица, тутовый шелкопряд. - М., 1983. - Вып. 3. - 184 с.

10. Методика державного сортовипробування сільськогосподарських культур. Загальна частина. - К., 2000. - Вип. 1. - 100 с.

11. Методические указания по определению биохимических показателей качества масла и семян масличных культур. - Краснодар, 1986. - 88 с.

12.Насінництво і насіннєзнавство польових культур / [за ред. М. М. Гаврилюка]. - К.: Аграрна наука, 2007. - 216 с. 
В статье приведены результаты изучения сестринских стерильных гибридов подсолнечника, полученных с участием индуцированных мутантных линий. Установлены тенденции в изменении основных хозяйственных признаков и выделены ценные комбинации, которые значительно превышают исходную форму по урожайности калиброванных семян, что подтверждает целесообразность использования сестринских гибридов в повышении урожайности материнских форм подсолнечника.

The results of the study of sister sterile hybrids of sunflower obtained with participation of the induced mutant lines are shown in the paper. Some tendencies in the variation of major economic traits are established and the best combinations being considerably superior over the initial form by graded seeds' yield are distinguished that confirms the expediency for the use of sister hybrids in grain yield increase of maternal forms of sunflower. 